УДК 351.86:659.3/.4:004](477)

DOI https://doi.org/10.32851/tnv-pub.2021.3.11

\title{
ФОРМУВАННЯ УКРАЇНСЬКОГО ГУМАНІТАРНОГО ПРОСТОРУ В КОНТЕКСТІ ЗАБЕЗПЕЧЕННЯ НАЦІОНАЛЬНОЇ БЕЗПЕКИ ДЕРЖАВИ
}

\author{
Неймарк О.А. - аспірант кафедри глобальної та національної безпеки \\ Навчально-наукового інституту публічного управління та державної служби \\ Київського національного університету імені Тараса Шевченка \\ ORCID: 0000-0002-2149-9125
}

У статті висвітлюється важливість і актуальність формування єдиного гуманітарного простору краӥни, який буде сприяти консолідаиії украӥнського народу, його об'єднанню в умовах посилення зовнішніх загроз, зокрема гібридної агресії з боку Російськоі Федерачії, формуванню загальноукраїнської ідентичності. Підкреслюється, що саме гуманітарні чинники лежать в основі й економічної, і військової безпеки, оскільки, коли нівелюється начіональна самосвідомість, втрачається власна мова, історія, почуття патріотизму та пошани до рідної держави, то начія та держава приречені на деградаиію та вимирання. Серед проблем, що гальмують розвиток гуманітарної політики в Україні, слід виділити: недостатність фінансування (здебільшого культура фінансується за залишковим принципом), недостатній рівень розвитку державного менеджменту, недосконалість законодавчої бази, недостатню ефективність гуманітарної політики на різних рівнях управління, відсутність потужного аналітичного забезпечення галузі, низький рівень матеріально-технічного й кадрового забезпечення тощо. Акцентується увага на необхідності підтримки української мови, культури, збереження та популяризації вітчизняної історико-культурної спадщини, розвитку освіти, науки тощо. Зазначається, що державна мова є потужним безпековим чинником, основними ознаками-проявами якого є утвердження єдиної національної ідентифікаџї̈ та консолідація українського суспільства на базі єдиного мовно-культурного простору; усвідомлення окремішності, самостійності та самодостатності свої нації-держави. Наголошується на важливості формування ефективної державної інформачійної політики, яка повинна протидіяти інформаційним загрозам із боку Російської Федерачії та сприяти побудові у краӥні потужного демократичного інформачійного суспільства, активному його входженню у світовий інформачійний простір.

Ключові слова: гуманітарний простір, начіональна безпека, національна ідентичність, культура, освіта, історична пам'ять, інформачійна політика

Neymark O.A. Ensuring the integrity and completeness of the Ukrainian humanitarian space as a task of national security

The article highlights the importance and urgency of forming a single humanitarian space of the country, which will contribute to the consolidation of the Ukrainian people, its unification in the face of growing external threats, including hybrid aggression by the Russian Federation, the formation of Ukrainian identity. It is emphasized that humanitarian factors underlie both economic and military security, because when national self-consciousness is leveled, one's own language, history, sense of patriotism and respect for one's homeland are lost, the nation and state are doomed to degradation and extinction. The importance of the linguistic factor, which has a significant security significance, as it contributes to the formation of a single linguistic and cultural space, is emphasized; awareness of the separateness, independence and self-sufficiency of their nation-state. Emphasis is placed on the importance of supporting Ukrainian culture, preservation and promotion of national historical and cultural heritage, development of education, science and more. It is pointed out that the problems of preservation and development of the existing network of cultural institutions in all regions of the country, providing them with modern material and technical base, stimulating the development of film production and improving film service, museum development, promoting the functioning and development of national creative unions of Ukraine, ensuring further cultural development of national minorities is 
different. The importance of forming an effective state information policy, which should counteract information threats from the Russian Federation and promote the construction of a strong democratic information society in the country, its active entry into the world information space, is emphasized.

Key words: humanitarian space, national identity, culture, education, historical memory, information policy.

Постановка проблеми. У сучасних глобалізаційних реаліях увагу потрібно приділяти гуманітарній сфері, оскільки загрози формуванню ціннісної самоідентифікації як окремої людини, так і певних соціальних та етнічних груп і держави загалом є досить актуальними. Державна підтримка української мови, національної культури, формування вітчизняної історичної пам'яті, збереження та популяризація історико-культурної спадщини, розвиток культурних індустрій є важливими завданнями гуманітарної політики держави, а подолання і попередження загроз у цих сферах, реалізація національних інтересів і захист національних цінностей - першочерговими завданнями політики забезпечення гуманітарної безпеки. Дуже важливо, щоб вона мала випереджувальний характер і не долала наслідки, а формувала би стратегію, що не допускала би розвитку негативних подій.

На сучасному етапі розвитку українського суспільства в умовах посилення гібридної агресії з боку Російської Федерації досить важливим є формування єдиного гуманітарного простору країни, який сприятиме консолідації українського народу, його об'єднанню в умовах посилення зовнішніх загроз, формуванню загальноукраїнської ідентичності. Світоглядні, мовні, культурні та ментальні відмінності нашого суспільства часто викликають проблеми, замість того, щоб стати основою іiі цивілізаційного розмаїття. Заважає об'єднанню українського суспільства і ставлення владних структур країни до своїх громадян та долі нашої країни, часто неефективне ведення внутрішньої та зовнішньої політики, зволікання із проведенням важливих соціально-економічних реформ, неузгоджена позиція гілок влади.

Аналіз останніх досліджень і публікацій. Дослідженням гуманітарних чинників забезпечення національної безпеки займалися як вітчизняні, так і зарубіжні науковці, зокрема Є. Магда, В. Горбулін, С. Здіорук, М. Степико, О. Литвиненко, Л. Чупрій, О. Кузьмук, В. Бакальчук, Т. Герасимчук, С. Хантінгтон, 3. Бжезінський, Г. Кісінджер, В. Копійка, І. Тодоров, В. Халаджі, Ф. Фукуяма. Х. Воллес, А. Гіддес, Р. Купер, Д. Рейнольдс, Дж. Стефен, Д. Чайлдз та ін.

Мета статті - проаналізувати особливості формування єдиного гуманітарного простору країни в умовах посилення зовнішніх загроз, зокрема гібридної агресії з боку Російської Федерації.

Виклад основного матеріалу. Слід виділити низку проблем, які досить довго існують у нашій державі та негативно впливають на формування національної ідентичності. Такими проблемними питаннями є: розбіжності у суспільстві стосовно мовної політики, вступу до НАТО, оцінки історичних подій, розвитку відносин із ЄС. Гострота таких питань зазвичай посилюється у період виборів, здебільшого політиками, котрі використовують такі конфронтаційні питання у власних цілях.

Сьогодні в українському суспільстві панують переважно негативні настрої щодо того, яким чином потрібно об'єднувати та консолідувати українське суспільство. Це стосується насамперед песимістичних оцінок майбутнього розвитку країни, невдоволення владою, переживання кризового стану політичної системи та розвитку економіки [1]. 
Проведене соціологічне опитування громадян України стосовно чинників консолідації та роз'єднання українського суспільства показало, що консолідації українського суспільства сприятимуть [2]:

- подолання важливих соціально-економічних проблем, підвищення добробуту населення України;

- подолання корупційних явищ і притягнення винних до відповідальності;

- зміна влади в Україні чесними, професійними, некорумпованими політиками;

- забезпечення справедливого розподілу суспільних благ, подолання значного розриву між багатими та бідними громадянами;

- посилення участі громадян у вирішенні ключових важливих проблем на державному та регіональному рівнях.

Основою для єднання жителів України стануть:

- спільне бачення майбутнього розвитку держави;

- спільні проблеми, які стоять перед українським народом сьогодні;

- спільна історія та спільне майбутнє.

Ці три чинники називають найважливішими для єднання жителі всіх регіонів.

Чинниками роз'єднання країни, на думку громадян, виступають:

- федералізація України;

- вступ до НАТО та ЄС;

- відмова від повернення тимчасово окупованих територій Криму та Донбасу [2].

Не менший вплив на перебіг консолідаційних процесів справляє і мовний фактор, який активно використовується Росією, щоб звинувачувати Україну у нібито порушеннях прав російськомовного населення. Всіх російськомовних остання сприймає як своїх активних прихильників, тож популяризація і підтримка української мови має важливе безпекове значення.

У цьому контексті Є. Магда пише, що українська мова справді залишається потужним засобом перетворення українського суспільства у націю. Вона сьогодні не $є$ тим чинником, який по справжньому розділяє українське суспільство на два протилежні табори. Найбільше вона штучно використовується для маніпуляцій, відвернення уваги населення від інших важливіших проблем суспільства [1].

Державна мова справді $є$ потужним безпековим чинником, основними ознаками-проявами якого $є$ утвердження єдиної національної ідентифікації та консолідація українського суспільства на базі єдиного мовно-культурного простору; усвідомлення окремішності, самостійності та самодостатності своєї нації-держави. Недосконалість дісвих правових механізмів утвердження української мови як державної гальмує реалізацію української національної державності, стоїть на перешкоді соціальному партнерству та національній консолідації українського суспільства [3, с. 45].

Важливим чинником формування гуманітарного простору є також історична пам'ять. Сьогодні спостерігаємо помітні регіональні відмінності у сприйнятті та розумінні історичного минулого України. Соціокультурна проблематика сьогодні є предметом політичних і суспільних дискусій. Така ситуація може розцінюватися як своєрідний визначник для оцінки розуміння з боку політиків і громадян не лише минулого, а й нинішніх соціально- політичних процесів, оскільки історичні події відіграють значну роль у політично-партійній, ідеологічній ідентифікації політичних сил, сприяють ідеологічному самовизначенню та згуртуванню довкола себе прибічників та однодумців. В Україні такі теми є доволі дискусійними та спричиняють серйозний розкол у суспільстві. 
Незважаючи на активні заклики до консолідації та єдності українського народу, певні політичні сили активно використовують у своїй політичній діяльності, електоральному впливу сьогоднішні суперечності, які існують у гуманітарній сфері, чим посилюють тенденції деконсолідації суспільства, продовжуючи соціальним популізмом посилювати амбівалентність суспільства, розвивати стереотипи про регіони-донори та регіони-споживачі, міфи про «дві різні України».

Історична пам'ять є тією цінністю, котра об'єднує українське суспільство у різні часи, сприяє посиленню національного піднесення. Довкола окремих історичних подій і сьогодні тривають політичні баталії, внаслідок чого відбувається «перетягування» заради власної користі політичними опонентами визначних історичних постатей.

На формування гуманітарного простору активно впливають також етнополітичні проблеми в Україні, які є наслідком минулої імперської політики, що проводила депортації цілих народів і примусову русифікацію.

Водночас актуальними $є$ проблеми, створені певними зовнішніми структурами, зокрема проблема сепаратизму у Криму та на Донбасі, питання русинського руху на Закарпатті. Основною загрозою $є$ ігнорування проблем національних меншин із метою досягнення короткострокової вигоди, ігнорування можливостей формування спільної історичної пам'яті, яка би поєднала чи навіть нейтралізувала національні суперечності [1].

Це загрожує загальнонаціональній консолідації шляхом підживлення міжрегіонального протистояння та суперечностей між центром і регіонами, що й робили деякі політичні сили, зокрема «Партія регіонів», а сьогодні продовжує робити «Опозиційний блок “За життя”».

Нині в Україні актуальними залишаються проблеми збереження та розвитку існуючої мережі закладів культури в усіх регіонах країни, забезпечення наявної сучасною матеріально-технічною базою, стимулювання розвитку кіновиробництва та поліпшення кінообслуговування, розвитку музейної справи, сприяння функціонуванню та розвитку національних творчих спілок України, забезпечення подальшого культурного розвитку національних меншин, поліпшення умов творчої діяльності митців, покращення умов та оплати праці працівників закладів культури тощо.

До ключових проблем державної культурної політики належать:

- неефективне управління сферою культури;

- зниження рівня духовності українського народу;

- низький рівень культурного розвитку суспільства, моральний занепад населення;

- недостатній рівень підтримки вітчизняного кінематографу, культурних індустрій, книгодрукування, мистецтва;

- політичні спекуляції щодо проблем мови, історії, релігії тощо [4].

Серед проблем, що гальмують розвиток державної культурної політики в Україні, також слід виділити: недостатність фінансування (здебільшого культура фінансується за залишковим принципом), недостатній рівень розвитку державного менеджменту у сфері культури, недосконалість законодавчої бази, недостатню ефективність культурної політики на різних рівнях управління, відсутність потужного аналітичного забезпечення галузі, низький рівень матеріально-технічного та кадрового забезпечення тощо.

Тож сьогодні потрібно підтримувати українську культуру, зберігати і популяризувати українську історико-культурну спадщину, розвивати освіту, посилювати 
ролі державної мови як безпекового чинника в умовах триваючої гібридної війни. Зокрема, вважаємо доцільним здійснити таке [3, с. 45]:

- законодавчо визнати державну мову, поряд із прапором, гербом і гімном, символом української держави. Прояви зневаги до державної мови, публічний глум, а також іiі умисна дискредитація має розглядатися як порушення Конституції України й образа національної гідності як громадян, так і держави, що має передбачати адміністративну та кримінальну відповідальність;

- докорінно переглянути мовну політику держави, стежити за неухильним дотриманням профільного закону та безкомпромісним утвердженням української мови не лише у державних установах, військових формуваннях, але і скрізь у публічному просторі;

- активно підтримувати формування україномовного інформаційного простору на всій території держави. Натомість пропагування чи поширення російської мови (культури, церкви, ідеології «російського миру») як таке, що потенційно збільшує ймовірність захисту їх адептів, а отже, подальшої агресії з боку Росії, в інтересах державної безпеки має бути максимально обмежене;

- на державному рівні через відповідні міністерства та відомства організувати роз'яснювальну й агітаційну роботу щодо поширення української мови, особливо у східних і південних областях України.

У сучасних умовах важливим залишається питання розроблення нової концепції державної політики у сфері культури, яка грунтуватиметься на таких ключових складниках:

- збереженні національної української ідентичності та самобутності;

- розумінні того, що культура є найважливішим суспільним благом, за допомогою якого цивілізоване суспільство забезпечує собі добробут;

- вивченні, узагальненні та систематизації провідного вітчизняного та зарубіжного досвіду діяльності держави у цій сфері;

- забезпеченні конкурентоспроможності закладів культури й українського культурного продукту на внутрішньому та зовнішньому ринках;

- активному впровадженні у сферу культури новітніх інноваційних технологій, оновленні матеріально-технічної й інфраструктурної бази закладів культури, зокрема їхнього інформаційного та програмного забезпечення;

- розробленні чітких критеріїв ефективності такої політики [3].

Головною метою національно-культурної програми розвитку культури і мистецтва в Україні мають стати [5, с. 168]:

- підтримка та розвиток наявної мережі культурно-мистецьких закладів, поліпшення їх матеріально-технічної бази, активніше впровадження у сфері культури новітніх інформаційних технологій;

- виробництво та популяризація вітчизняного культурно-мистецького продукту серед різних груп населення;

- створення позитивного образу української культури як у власній країні, так і за кордоном;

- збереження історико-культурної спадщини, підтримка музейної галузі, сприяння поверненню в Україну культурних цінностей;

- активізація державної підтримки сучасного українського мистецтва, зокрема створення культурно-мистецьких програм для радіо і телебачення, поширення відповідного контенту в Інтернет-мережі;

- підтримка бібліотечної галузі, зокрема постійне оновлення бібліотечних фондів через закупку різноманітної літератури українською мовою та мовами на- 
ціональних меншин, активне впровадження новітніх інформаційних технологій у бібліотечній галузі;

- підтримка та розвиток етнічної, соціокультурної, мовної та релігійно-конфесійної самобутності різноманітних національних меншин України з обов'язковою підтримкою українського етносу як титульного;

- забезпечення міжнаціонального та міжконфесійного діалогу.

На нашу думку, сьогодні Україна потребує розробки нової концепції державної політики у сфері культури, в основі якої лежатиме чітке визнання необхідності забезпечення конкурентоспроможності закладів культури; активне впровадження у сферу культури новітніх інноваційних технологій, оновлення матеріально-технічної та інфраструктурної бази закладів культури; розробка чітких критеріїв ефективності такої політики.

Для розвитку вітчизняного кінематографу необхідним є: підвищення ефективності системи державного управління у сфері кінематографії, підтримка продюсерської діяльності, розширення державного замовлення у сфері кіноіндустрії на сучасні українські фільми, що популяризують українську історію, сприяють формуванню національних цінностей, створення широкої мережі кінопрокату. Загалом розвиток сфери кінематографії є одним із важливих напрямів державної культурної політики [6, с. 89].

Для розвитку книговидавничої галузі України необхідним є: розроблення ефективних механізмів взаємодії органів державної влади, керівництва територіальних громад із книговидавничими організаціями та громадськими об'єднаннями щодо розвитку вітчизняної книги; розроблення Стратегії розвитку книговидання в Україні; залучення інвестицій у видавничо-поліграфічну галузь зі звільненням від оподаткування коштів, які вкладаються у вітчизняне книговидання, зокрема меценатських і спонсорських коштів, що підтримують вітчизняну книгу. Активна державна підтримка вітчизняного книговидання та книгорозповсюдження повинна забезпечити підвищення попиту на книжкову продукцію та перетворення його на прибутковий бізнес.

Державна політика повинна бути зосереджена на вдосконаленні законодавства та запровадженні податкових пільг, контролі над випуском соціально важливих видань, збільшенні кількості державних видавництв, контролі над імпортом видавничої продукції в Україну. Бюджетні кошти мають розподілятися тільки після вивчення ситуації на ринку, потреб бібліотек, освітніх і наукових установ задля реалізації актуального та стратегічно важливого знання, 3 дотриманням вимог чинного законодавства [7, с. 40].

Також сьогодні дуже важливо створити підвалини для формування стабільного і безпечного інформаційного простору в Україні в умовах гібридної агресії з боку Російської Федерації, а також сприяти його інтеграції у світовий інформаційний простір. Держава повинна на належному рівні забезпечити інформаційну безпеку людини, суспільства та держави, розширити перелік вітчизняних інформаційних послуг для населення [8, с. 82].

Метою державної інформаційної політики повинна стати побудова у країні потужного демократичного інформаційного суспільства, активне його входження у світовий інформаційний простір. Для реалізації цього завдання потрібно сприяти створенню всіх умов для розвитку та забезпечення системного використання інформаційних ресурсів у всіх сферах діяльності.

Потрібно також забезпечити створення сприятливих умов для формування, розвитку, модернізації та використання національних інформаційних ресурсів, 
інформаційно-телекомунікаційної інфраструктури та технологій. Перед цим має бути проведений детальний аналіз наявної нормативно-правової бази та визначення шляхів і напрямів ії удосконалення з урахуванням сучасних реалій розвитку суспільства [8, с. 83].

Інформаційна політика також повинна сприяти забезпеченню інформаційної безпеки, зокрема збереженню державної таємниці, захисту інформаційно-телекомунікаційної інфраструктури й інформаційних ресурсів від кібератак та інших загроз в інформаційному просторі. Потрібно посилити й удосконалити вітчизняні системи інформаційного захисту [8, с. 83].

Сьогодні в умовах посилення інформаційних і кібератак із боку Російської Федерації й активного застосування новітніх інформаційних технологій досить актуальною $є$ кібербезпека. Зокрема, у нашій країні затверджена Стратегія кібербезпеки, серед ключових завдань якої ми виділяємо [9]:

- посилення спроможності національної системи кібербезпеки для унеможливлення збройної агресії проти України у кіберпросторі або з його використанням, нейтралізації розвідувально-підривної діяльності, мінімізації загроз кіберзлочинності та кібертероризму (стримування);

- підтримку технологій кіберзахисту засобів рухомого зв'язку, забезпеченні апаратної, контентної безпеки, безпеки додатків і сервісів зв’язку [9].

Висновки 3 дослідження. Підсумовуючи, слід зазначити, що для формування гуманітарного простору держави потрібно вирішити низку першочергових завдань, таких як:

- Розвиток вітчизняних культурних індустрій.

- Зміцнення освітнього та науково-технологічного потенціалу країни.

- Розвиток програм збереження та популяризації історико-культурної спадщини $[10$, с. 36$]$.

- Формування ефективної державної політики пам'яті.

- Гармонізація державно-конфесійних відносин.

- Розробка та реалізація Концепції державної етнонаціональної політики України.

- Розробка системних заходів щодо захисту інформаційного простору держави.

- Створення умов для формування потужного середнього класу як важливого суспільно стабілізуючого чинника.

- Децентралізація влади, збільшення повноважень і фінансових можливостей місцевих органів влади.

\section{СПИСОК ВИКОРИСТАНОЇ ЛІТЕРАТУРИ:}

1. Магда Є.В. Сучасні загрози консолідації українського суспільства. URL: https://core.ac.uk/download/ pdf/32608515.pdf.

2. Консолідація українського суспільства: шляхи, виклики, перспективи. URL: http://razumkov.org.ua/ upload/Identi-2016.pdf.

3. Чеховська М.М., Шлапаченко В.М. Мова як чинник національної безпеки. Держава та регіони. 2018. № 3. С. 39-46.

4. Піньковська Г.В. Оцінка сучасного стану розвитку культурного середовища регіонів України. Ефективна економіка. 2018. № 10. URL: http://www.economy. nayka.com.ua/?op=1\&z=3424.

5. Доманська О. Роль держави в реалізації культурної політики: концептуальний вимір. Релігія та Соиіум. 2014. № 3-4 (15-16). С. 163-169.

6. Кучин С.П. Кінематографічна сфера як об’єкт державної культурної політики України. Інвестицї:: практика та досвід. 2017. № 2. С. 86-89. 
7. Демуз І.О. Державний видавничий сектор України: проблеми та перспективи розвитку. Економічний вісник університету. 2017. Вип. 35/1. С. 32-41.

8. Негодченко В. Основні напрями державної інформаційної політики в Україні. Підприємництво, господарство і право. 2016. № 4. С. 77-81.

9. Указ Президента України № 447/2021 «Про рішення Ради національної безпеки і оборони України від 14 травня 2021 р. "Про Стратегію кібербезпеки України"». URL: https://www.president.gov.ua/documents/4472021-40013.

1. Чупрій Л.В. Концептуальні засади політики національної безпеки держави в гуманітарній сфері. Політичний менеджмент. № 1-2. 2013. С. 35-41.

\section{REFERENCES:}

1. Mahda Ye.V. (2013). Suchasni zahrozy konsolidatsii ukrainskoho suspilstva [Modern threats to the consolidation of Ukrainian society ]. Istoryko-politychni studii, 2013, № 1, S. 107-113. [in Ukrainian].

2. Konsolidatsiia ukrainskoho suspilstva: shliakhy, vyklyky, perspektyvy (2016). [Language as a factor of national security]. URL: http://razumkov.org.ua/upload/ Identi-2016.pdf [in Ukrainian].

3. Chekhovska M.M., Shlapachenko V.M. (2018). Mova yak chynnyk natsionalnoi bezpeky. Derzhava ta rehiony, № 3, S. 39-46 [in Ukrainian].

4. Pinkovska H.V. (2018). Otsinka suchasnoho stanu rozvytku kulturnoho seredovyshcha rehioniv Ukrainy [Estimation of the current state of development of the cultural environment of the regions of Ukraine ]. Efektyvna ekonomika, № 10, S. 44-56. [in Ukrainian].

5. Domanska O. (2014). Rol derzhavy v realizatsii kulturnoi polityky: kontseptualnyi vymir [The role of the state in the implementation of cultural policy: a conceptual dimension]. Relihiia ta Sotsium, № 3-4 (15-16), S. 163-169 [in Ukrainian].

6. Kuchyn S.P. (2017). Kinematohrafichna sfera yak obiekt derzhavnoi kulturnoi polityky Ukrainy [Cinematographic sphere as an object of state cultural policy of Ukraine]. Investytsii: praktyka ta dosvid, № 2, S. 86-89 [in Ukrainian].

7. Demuz I.O. (2017). Derzhavnyi vydavnychyi sektor Ukrainy: problemy ta perspektyvy rozvytku [State publishing sector of Ukraine: problems and prospects of development]. Ekonomichnyi visnyk universytetu, Vyp. 35/1, S. 32-41. [in Ukrainian].

8. Nehodchenko V. (2016). Osnovni napriamy derzhavnoi informatsiinoi polityky v Ukraini [The main directions of the state information policy in Ukraine]. Pidpryiemnytstvo, hospodarstvo i pravo, № 4, S. 77-81 [in Ukrainian].

9. Ukaz prezydenta Ukrainy № 447/2021 "Pro rishennia Rady natsionalnoi bezpeky i oborony Ukrainy vid 14 travnia 2021 r. "Pro Stratehiiu kiberbezpeky Ukrainy" [Decree of the President of Ukraine № 447 / 2021 "On the decision of the National Security and Defense Council of Ukraine of May 14, 2021 "On the Cyber Security Strategy of Ukraine"] URL: https://www.president.gov.ua/documents/4472021-40013 [in Ukrainian].

10. Chuprii L.V. (2013). Kontseptualni zasady polityky natsionalnoi bezpeky derzhavy $\mathrm{v}$ humanitarnii sferi [Conceptual bases of the national security policy of the state in the humanitarian sphere]. Politychnyi menedzhment, № 1-2, S. 35-41. [in Ukrainian]. 